\title{
RESIDUAL EFFECT OF FODDERS ON THE SUCCEEDING RICE CROP
}

\section{BINDHYA, B. N \& JACOB JOHN*}

Department of Agronomy, College of Agriculture, Vellayani, Thiruvananthapuram, Kerala, India

KEYWORDS: Residual Effect, Rice, Fodder Crops, Fodder Cowpea, Rice Bean, Fodder Maize, Fodder Sorghum, Nitrogen, Summer Rice Fallow

Received: Nov 01, 2020; Accepted: Nov 30, 2020; Published: Dec 17, 2020; Paper Id.: IJASRDEC20201

\section{INTRODUCTION}

The rice based cropping system is a potential platform for residual or carry over effects of one crop to act up on the succeeding ones. In Southern Kerala the major rice based system followed is rice-rice-summer fallow (John et al., 2014). Judicious integration of fodder crops in the summer rice fallows increases the fodder availability along with enhanced system productivity. In addition to that, the incorporated rice stubble offers a chance to reduce application of chemical fertilizers specially the nitrogenous fertilizers, where nitrogen concentration in the rice straw alone ranges from 0.4 to 0.7 on dry weight basis (Williams et al., 1968). It is to be noted that, $75 \%$ of anthropogenic nitrogen source comes under the leached agricultural inputs, i.e. fertilizers and manures (Mosier $e t$ al., 1996). Further, the legume effect in rice based cropping system enhanced the grain yield of rice, which is often accomplished through increased plant height, increased productive tillers, tiller number or straw yields (Mridha, 1987). However, the decline in the yield of rice in the rice based cropping system can be due the exhaustive nature of cereals included in the system (Jadhav, 1989). Rice subsequent to forage legumes recorded a yield increase of 0.6 to $2.4 \mathrm{t} \mathrm{ha}^{-1}$ (Carangal et al. 1994; Ladha et al. 1996). The wider C: N ratio of sorghum and Sudan grass reduced the availability of $\mathrm{N}$ to the subsequent crops despite the accumulated $\mathrm{N}$ in the crop residues long considerable (Sattell et al., 1998). Ramachandra et al. (2007) observed that the average yield of rice or fodder maize in sequence declined, whereas more or less equal yield was obtained for rice succeeding legumes. Toaima $e t$ al. (2014) reported that Sudan grass had positive allelopathic effect on the subsequent crops of berseem, faba bean 
and onion on forage yield, seed yield and bulb yield respectively. But the yield of fodder beet, wheat and sugar beet declined when grown after Sudan grass and sorghum compared to the fallow treatments.

Considering all these factors, the study was undertaken to assess the residual effect of fodder crops under varying regimes of nitrogen on the growth and yield of succeeding rice crop.

\section{MATERIALS AND METHODS}

In the experiment, fodder crops were raised during the period of summer 2018 (February $21^{\text {st }}$ to $11^{\text {th }}$ May) and the succeeding viripp $u$ rice crop (var. Uma) was taken up during $11^{\text {th }}$ June $-26^{\text {th }}$ October, 2018. The site of experiment was double cropped low land rice fields of Integrated Farming System Research Station of Kerala Agricultural University located at Karamana, Thiruvananthapuram. The study on residual effect was concentrated only in virippu rice crop, where minimum temperature during the period ranged from 20.07 to $24.64^{\circ} \mathrm{C}$ and the maximum temperature varied from 28.28 to $32.21{ }^{\circ} \mathrm{C}$. The relative humidity of the area ranged from 75.07 to 93.85 per cent. The total rain fall received during the virippu season was $898.48 \mathrm{~mm}$. The soil in the site of experiment was sandy clay loam in texture, moderately acidic with normal electric conductivity, medium in OC, available $\mathrm{N}, \mathrm{P}$ and $\mathrm{K}$.

The experiment was laid out in Randomized Block Design with thirteen treatments. In the summer fallow, four fodder crops viz., fodder cowpea (FC), rice bean (RB), fodder maize (FM) and fodder sorghum (FS) were raised under three levels of nitrogen viz., $100 \% \mathrm{RDN}, 75 \% \mathrm{RDN}$ and 50\% RDN. Rice var. Uma raised in the virippu season. The treatments were $\mathrm{T}_{1}$ : Rice succeeding FC with $100 \% \mathrm{RDN}, \mathrm{T}_{2}$ : Rice succeeding FC with $75 \% \mathrm{RDN}, \mathrm{T}_{3}$ : Rice succeeding FC with $50 \%$ RDN, $\mathrm{T}_{4}$ : Rice succeeding RB with $100 \% \mathrm{RDN}, \mathrm{T}_{5}$ : Rice succeeding RB with $75 \% \mathrm{RDN}, \mathrm{T}_{6}$ : Rice succeeding RB with 50\% RDN, $\mathrm{T}_{7}$ : Rice succeeding FM with $100 \%$ RDN, $\mathrm{T}_{8}$ : Rice succeeding FM with 75\% RDN, $\mathrm{T}_{9}$ : Rice succeeding FM with 50\% RDN, $\mathrm{T}_{10}$ : Rice succeeding FS with $100 \%$ RDN, $\mathrm{T}_{11}$ : Rice succeeding FS with $75 \%$ RDN, $\mathrm{T}_{12}$ : Rice succeeding FS with 50\% RDN, $\mathrm{T}_{13}$ : Rice succeeding summer fallow (control treatment). All the treatments were replicated thrice. Plot size was $5 \mathrm{~m}$ x 4m. The fodder cowpea variety used was CO 9 released from TNAU. It is of short duration (50 to 55 days), dwarf with reduced fibre portions which confers increased digestibility, palatability and intake. Bidhan-2 variety of rice bean released from Bidhan Chandra Krishi Viswavidyalaya (BCKV), Kalyani, West Bengal was used for the study. The variety has erect growth habit during early growth stage which later on becomes viny with indeterminate and luxuriant growth. The legume has profuse branching nature and grows to a height of 150 to $160 \mathrm{~cm}$. Fodder maize variety African Tall was used which is bred at Mahatma Phule Krishi Vidyapeeth (MPKV), Kolhapur and is a composite of seven genotypes developed through modified mass selection. The average plant height is $260 \mathrm{~cm}$. Fodder sorghum variety CO (FS) 31 was used for the study which is developed by TNAU, Coimbatore. It is a multi cut variety having a height of 270 to $290 \mathrm{~cm}$. The rice variety used was Uma (MO-16) released from Rice Research Station, Moncompu, Alapuzha, Kerala Agricultural University. It is of medium duration (115 to120 days), dwarf, medium tillering, non-lodging and resistant to brown plant hopper. Manures and fertilizers were applied as per the recommendations of TNAU for fodder cowpea, fodder maize and fodder sorghum. For rice bean as per the recommendations of AICRP on Forage crops and for the rice crop as per the Package of Practices of Kerala Agricultural University (KAU, 2016). Well decomposed FYM containing 0.5 per cent N, 0.2 per cent $\mathrm{P}_{2} \mathrm{O}_{5}$ and 0.4 per cent $\mathrm{K}_{2} \mathrm{O}$ was applied as source of organic manure. Urea $(46 \% \mathrm{~N})$, rock phosphate $\left(20 \% \mathrm{P}_{2} \mathrm{O}_{5}\right)$ and Muriate of potash $\left(\mathrm{K}_{2} \mathrm{O} 60 \%\right)$ were used as inorganic sources of $\mathrm{N}$, $\mathrm{P}$ and $\mathrm{K}$ respectively.

The residual effect of fodder crops under different levels of nitrogen on succeeding rice crop was assessed in terms 
differ significantly between treatments at 20 and 40 DAT, and harvest (Table 2). Also, there was no significant difference between the treatments and control at 20 and 40 DAT and harvest.

The number of productive tillers $\mathrm{m}^{-2}$ did not differ significantly between treatments (Table 3 ). The productive tillers $\mathrm{m}^{-2}$ did not differ significantly between treatments and control. The thousand grain weight was not significantly influenced by the treatments (Table 3). The thousand grain weight did not differ significantly between treatments and control. The data on yield and harvest index is furnished in Table 3. There was no significant difference between treatments in grain yield, straw yield and harvest index. The treatments and control also did not differ significantly in case of grain yield, straw yield and harvest index.

The gross income, net income and B: C ratio did not differ significantly between treatments (Table 4). Also, the gross income, net income and B: C ratio did not differ significantly between treatments and control.

With respect to growth and yield of the rice crop, plant height alone exhibited a significant difference between the treatments at 20 and 40 DAS and at harvest. But, there was no specific pattern in the observed differences in plant height with regard to the preceding crops or varying doses of nitrogen.

It can be inferred that, despite two of the fodder crops raised during summer being legumes, the expected legume effect was not evident in growth or yield of rice. It is also interesting that reducing the level of $\mathrm{N}$ to the crops raised during summer did not have any adverse effect on the first crop of rice. The experiment was under taken in a field with a history of rice-rice-fallow sequence for the past several years. The stubble of the first and second crop was regularly incorporated in the soil. Moreover, the weeds of the summer fallow were also recycled. This might have resulted in a stabilized nutrient cycle and helped to override the adverse effect expected out of a reduction in $\mathrm{N}$ dose for the summer crop. Further, reducing the RDN for the summer crops did not have any adverse effect on the productivity and economics of the succeeding rice crop. Neither negative nor positive residual effects due to the inclusion of fodder crops during summer or owing to reduction of $\mathrm{N}$ dose for the summer crops were observed in the succeeding rice crop. It is to be noted that the rice crop was supplied with the recommended organic manure and nutrients.

Table 1: Effect of Treatments on Plant Height of Succeeding Rice Crop, cm

\begin{tabular}{|l|c|c|c|}
\hline \multicolumn{1}{|c|}{ Treatments } & 20 DAT & 40 DAT & At harvest \\
\hline $\mathrm{T}_{1}:$ Rice succeeding FC with 100 \% N & 30.47 & 54.18 & 91.20 \\
\hline $\mathrm{T}_{2}:$ Rice succeeding FC with 75 \% N & 29.80 & 51.27 & 95.48 \\
\hline $\mathrm{T}_{3}:$ Rice succeeding FC with 50 \% N & 30.30 & 57.35 & 95.70 \\
\hline $\mathrm{T}_{4}:$ Rice succeeding RB with 100\% N & 31.83 & 56.08 & 96.97 \\
\hline $\mathrm{T}_{5}:$ Rice succeeding RB with 75\% N & 31.74 & 52.81 & 95.47 \\
\hline $\mathrm{T}_{6}:$ Rice succeeding RB with 50\% N & 32.32 & 52.37 & 96.63 \\
\hline $\mathrm{T}_{7}:$ Rice succeeding FM with 100\% N & 28.53 & 55.49 & 98.68 \\
\hline $\mathrm{T}_{8}:$ Rice succeeding FM with 75 \% N & 31.90 & 54.18 & 98.13 \\
\hline $\mathrm{T}_{9}:$ Rice succeeding FM with 50\% N & 32.97 & 54.01 & 95.57 \\
\hline $\mathrm{T}_{10}:$ Rice succeeding FS with100\% N & 29.70 & 55.78 & 99.47 \\
\hline $\mathrm{T}_{11}:$ Rice succeeding FS with75\% N & 33.38 & 55.80 & 97.90 \\
\hline $\mathrm{T}_{12}:$ Rice succeeding FS with 50\% N & 33.70 & 56.67 & 96.03 \\
\hline $\mathrm{T}_{13}:$ Rice succeeding summer fallow & 28.59 & 54.91 & 97.20 \\
\hline SEm $( \pm)^{*}$ & 0.892 & 2.055 & 1.060 \\
\hline CD $(0.05)^{* *}$ & 2.617 & 6.027 & 3.110 \\
\hline Treatment vs. control & $\mathrm{S}$ & $\mathrm{NS}$ & $\mathrm{NS}$ \\
\hline
\end{tabular}

*Standard Error of Mean

**Critical Difference 
Table 2: Effect of Treatments on Number of Tillers $\mathbf{~ m}^{-2}$ of Succeeding Rice Crop

\begin{tabular}{|c|c|c|c|}
\hline Treatment & 20 DAT & 40 DAT & At harvest \\
\hline $\mathrm{T}_{1}$ : Rice succeeding FC with $100 \% \mathrm{~N}$ & 100 & 585 & 377 \\
\hline $\mathrm{T}_{2}:$ Rice succeeding FC with $75 \% \mathrm{~N}$ & 107 & 496 & 329 \\
\hline $\mathrm{T}_{3}$ : Rice succeeding FC with $50 \% \mathrm{~N}$ & 139 & 551 & 308 \\
\hline $\mathrm{T}_{4}$ : Rice succeeding RB with $100 \% \mathrm{~N}$ & 108 & 525 & 341 \\
\hline $\mathrm{T}_{5}:$ Rice succeeding RB with $75 \% \mathrm{~N}$ & 128 & 524 & 304 \\
\hline $\mathrm{T}_{6}$ : Rice succeeding RB with $50 \% \mathrm{~N}$ & 89 & 493 & 330 \\
\hline $\mathrm{T}_{7}:$ Rice succeeding FM with $100 \% \mathrm{~N}$ & 119 & 517 & 332 \\
\hline $\mathrm{T}_{8}:$ Rice succeeding FM with $75 \% \mathrm{~N}$ & 133 & 580 & 309 \\
\hline $\mathrm{T}_{9}$ : Rice succeeding FM with $50 \% \mathrm{~N}$ & 127 & 526 & 323 \\
\hline $\mathrm{T}_{10}:$ Rice succeeding FS with $100 \% \mathrm{~N}$ & 119 & 503 & 337 \\
\hline $\mathrm{T}_{11}:$ Rice succeeding FS with $75 \% \mathrm{~N}$ & 120 & 459 & 362 \\
\hline $\mathrm{T}_{12}$ : Rice succeeding FS with $50 \% \mathrm{~N}$ & 97 & 528 & 337 \\
\hline $\mathrm{T}_{13}$ : Rice succeeding summer fallow & 111 & 495 & 283 \\
\hline SEm $( \pm)$ & 14.13 & 53.53 & 27.07 \\
\hline $\mathrm{CD}(0.05)$ & NS & NS & $\mathrm{NS}$ \\
\hline Treatment vs. control & NS & NS & NS \\
\hline
\end{tabular}

Table 3: Effect of Treatments on Yield Attributes and Yield of Succeeding Rice

\begin{tabular}{|c|c|c|c|c|c|}
\hline Treatment & 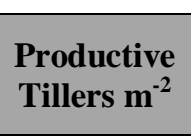 & $\begin{array}{l}\text { Thousand } \\
\text { Grain } \\
\text { Weight (g) }\end{array}$ & $\begin{array}{c}\text { Grain Yield } \\
\left(\mathrm{kg} \mathrm{ha}^{-1}\right)\end{array}$ & $\begin{array}{c}\text { Straw } \\
\text { Yield } \\
\left(\mathrm{kg} \mathrm{ha}^{-1}\right)\end{array}$ & $\begin{array}{c}\text { Harvest } \\
\text { Index }\end{array}$ \\
\hline $\mathrm{T}_{1}$ : Rice succeeding FC with $100 \% \mathrm{~N}$ & 296 & 25.88 & 3750 & 4667 & 0.45 \\
\hline $\mathrm{T}_{2}:$ Rice succeeding FC with $75 \% \mathrm{~N}$ & 268 & 25.19 & 3250 & 3833 & 0.46 \\
\hline $\mathrm{T}_{3}:$ Rice succeeding FC with $50 \% \mathrm{~N}$ & 267 & 24.96 & 3417 & 4125 & 0.45 \\
\hline $\mathrm{T}_{4}$ : Rice succeeding RB with $100 \% \mathrm{~N}$ & 240 & 25.21 & 3333 & 3625 & 0.48 \\
\hline $\mathrm{T}_{5}:$ Rice succeeding RB with $75 \% \mathrm{~N}$ & 254 & 24.21 & 2967 & 3367 & 0.47 \\
\hline $\mathrm{T}_{6}$ : Rice succeeding RB with $50 \% \mathrm{~N}$ & 251 & 24.46 & 3250 & 3750 & 0.47 \\
\hline $\mathrm{T}_{7}:$ Rice succeeding FM with $100 \% \mathrm{~N}$ & 284 & 24.93 & 3375 & 3875 & 0.47 \\
\hline $\mathrm{T}_{8}:$ Rice succeeding FM with $75 \% \mathrm{~N}$ & 263 & 24.76 & 3250 & 3792 & 0.46 \\
\hline $\mathrm{T}_{9}:$ Rice succeeding FM with $50 \% \mathrm{~N}$ & 267 & 24.21 & 3083 & 3792 & 0.45 \\
\hline $\mathrm{T}_{10}$ : Rice succeeding FS with100 \% N & 307 & 24.48 & 4000 & 4667 & 0.46 \\
\hline $\mathrm{T}_{11}$ : Rice succeeding FS with75 \% N & 311 & 24.13 & 3667 & 4042 & 0.47 \\
\hline $\mathrm{T}_{12}$ : Rice succeeding FS with $50 \% \mathrm{~N}$ & 283 & 24.31 & 3250 & 3958 & 0.45 \\
\hline $\mathrm{T}_{13}:$ Rice succeeding summer fallow & 235 & 23.39 & 3167 & 3500 & 0.47 \\
\hline $\operatorname{SEm}( \pm)$ & 19.99 & 0.52 & 257.01 & 284.87 & 0.02 \\
\hline $\mathrm{CD}(0.05)$ & NS & NS & NS & NS & NS \\
\hline Treatment vs. control & NS & NS & NS & NS & NS \\
\hline
\end{tabular}

Table 4: Effect of Treatments on Economics of Cultivation of Succeeding Crop of Rice

\begin{tabular}{|c|c|c|c|}
\hline Treatment & $\begin{array}{l}\text { Gross Income } \\
\left(₹ \mathrm{ha}^{-1}\right)\end{array}$ & $\begin{array}{l}\text { Net Income } \\
\left(₹ \mathrm{ha}^{-1}\right)\end{array}$ & B:C Ratio \\
\hline $\mathrm{T}_{1}:$ Rice succeeding FC with $100 \% \mathrm{~N}$ & 135833 & 45833 & 1.51 \\
\hline $\mathrm{T}_{2}:$ Rice succeeding FC with $75 \% \mathrm{~N}$ & 116667 & 26667 & 1.30 \\
\hline $\mathrm{T}_{3}$ : Rice succeeding FC with $50 \% \mathrm{~N}$ & 123125 & 33125 & 1.37 \\
\hline $\mathrm{T}_{4}$ : Rice succeeding RB with $100 \% \mathrm{~N}$ & 118125 & 28125 & 1.31 \\
\hline $\mathrm{T}_{5}:$ Rice succeeding RB with $75 \% \mathrm{~N}$ & 105833 & 15833 & 1.18 \\
\hline $\mathrm{T}_{6}:$ Rice succeeding RB with $50 \% \mathrm{~N}$ & 116250 & 26250 & 1.29 \\
\hline $\mathrm{T}_{7}:$ Rice succeeding FM with $100 \% \mathrm{~N}$ & 120625 & 30625 & 1.34 \\
\hline $\mathrm{T}_{8}$ : Rice succeeding FM with $75 \% \mathrm{~N}$ & 116458 & 26458 & 1.29 \\
\hline $\mathrm{T}_{9}:$ Rice succeeding FM with $50 \% \mathrm{~N}$ & 111458 & 21458 & 1.24 \\
\hline
\end{tabular}




\begin{tabular}{|l|c|c|c|}
\hline $\mathrm{T}_{10}:$ Rice succeeding FS with $100 \% \mathrm{~N}$ & 143333 & 53333 & 1.59 \\
\hline $\mathrm{T}_{11}:$ Rice succeeding FS with75\% N & 130208 & 40208 & 1.45 \\
\hline $\mathrm{T}_{12}:$ Rice succeeding FS with 50\% N & 117292 & 27292 & 1.30 \\
\hline $\mathrm{T}_{13}:$ Rice succeeding summer fallow & 112500 & 22500 & 1.25 \\
\hline $\mathrm{SEm}( \pm)$ & & 8637.35 & 0.09 \\
\hline CD $(0.05)$ & & $\mathrm{NS}$ & $\mathrm{NS}$ \\
\hline Treatment vs. control & & $\mathrm{NS}$ & $\mathrm{NS}$ \\
\hline
\end{tabular}

\section{AKNOWLEDGEMENT}

The authors are grateful to the Kerala Agricultural University for the financial assistance for the successful conduct of the research work.

\section{REFERENCES}

1. Carangal, V. R., Rebancos, E. T., Jr., Armada, E. C and Tengco, P. L. 1994. Green manure production systems for Asian Rice Lands. International rice research institute, Los Banos, Philippines. 132p.

2. Cochran, W. G. and Cox, G. M. 1965. Experimental Designs. John Willey and Sons Inc., New York, 182p.

3. Donald, C. M. and Hamblin, J. 1976. The biological yield and harvest index of cereals as agronomic and plant breeding criteria. Adv. Agron. 28: 361-405.

4. Gomez, K. A. 1972. Techniques for Field Experiments with Rice. IRRI, Los Banos, Philippines. 49p.

5. Jadav, A.S. (1989). Nutrient balance with reference to fertilizer management under wheat based cropping system. J. Maharashtra Agric.Univ. 14 (3) :288-291.

6. KAU (Kerala Agricultural University) 2016. Package of Practices Recommendations: Crops (15th Ed.). Kerala Agricultural University, Thrissur, 393p.

7. Ladha, J. K., Kundu, D. K., Coppenolle, M. G. A., Peoples, M. B., Carangal, V. R., and Dart. P. J. 1996. Legume productivity and soil nitrogen dynamics in lowland rice based cropping systems. Soil Sci. Soc. of America J. 60:183-192.

8. Mosier, A. R., Duxbury, J. M., Freney, J. R., Heinemeyer, O., Minami, K. 1996. Nitrous oxide emissions from agricultural fields: Assessment, measurement and mitigation. Plant and Soil. 181: 95.

9. Mridha, M. A. J. 1987. Effect of the rate of green manuring on growth, yield and nitrogen uptake of BR3 rice. M.Sc. Thesis, Department of Agronomy, Bangladesh Agricultural University, Mymensingh, Bangladesh. 132p.

10. Ramachandra, C., Syed, M. A., Janardhan, G., and Murthy, P. 2007. Production potential and economics of rice-based cropping systems in hill zone of Karnataka, India. Int. J. Agric. Sci. 3(2): 127-129.

11. Sattell, R. R., Dick, R., Ingham, R., Karow, and McGrath, D. 1998. Sudangrass and sorghum-sudangrass hybrids. Oregon Cover Crops, Extension and Experiment Station, Oregon State University. Corvallis. 192p.

12. Toaima, S. E. A., Lamlom, M. M.,Wahab, A. T. I. and Wahab, S. I. A. 2014. Allelopathic effects of sorghum and Sudan grass on some following winter field crops. Int. J. of Plant \& Soil Sci. 3(6): 599-622.

13. Williams, W. A., Mikkelsen, D. S., Mueller, K. E, and Ruckman, J. E. 1968. Nitrogen immobilization by rice straw incorporated in lowland rice production. Plant and Soil. 28 (1): 49-60. 